\title{
The effects of choice feeding and season on the feeding behaviour and growth performance of calves $^{*}$
}

\author{
M. Gorgulu ${ }^{1,3}$, M.A. Akyol ${ }^{1}$, M. Boga ${ }^{2}$ and S. Goncu ${ }^{1}$

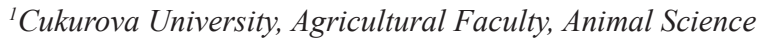 \\ 01330 Adana, Turkey \\ ${ }^{2}$ Nigde University, Bor Vocational School \\ Nigde, Turkey
}

(Received 17 June 2010; revised version 27 March 2012; accepted 18 June 2012)

\begin{abstract}
Two studies were performed to determine the effect of the selection of a diet from different feed ingredients offered on a free-choice basis and to determine the effect of the feeding method on the feeding behaviour and growth performance of calves in the pre-weaning period during different seasons. One-week-old Holstein Friesian calves were assigned to two experimental groups (choice feeding vs single feed). The diet was composed of, \%: barley 42.56 , maize 12 , soyabean meal- SBM, 5.92, maize gluten meal 9.6, wheat bran 6.96, and 20 lucerne hay (ground, 1.5-2 cm). The feed ingredients used in the single feed were offered on a free-choice basis to the choice-fed calves. All calves were fed ad libitum, and water was freely available. The daily eating patterns were recorded with a real-time data-collection system, including six electronic scale feeders. The studies were conducted for 10 weeks, including an 8-week pre-weaning period and a 2-week post-weaning period. The results showed that the calves had a higher rectal temperature, respiration and pulse rate during the summer than during the winter $(\mathrm{P}<0.05)$. The meal number and total meal time were higher during the summer than during the winter. Feed intake, daily gain, and feed-to-gain ratio did not change according to season, however. Choice feeding increased the number of meals and the rate of feed intake but decreased meal duration and the intermeal interval compared with single feed $(\mathrm{P}<0.05)$. The choice-fed calves selected totally different $(\mathrm{P}<0.01)$ diets than the single-fed calves (SBM: 5.9 vs $64.7 \%$, barley: 42.6 vs $8.4 \%$, lucerne hay: 20 vs $5.8 \%$ ). The calves did not change their diet preferences after weaning, compared with the pre-weaning period. Choice feeding increased nutrient intake due to increases in feed intake and diet preferences $(\mathrm{P}<0.05)$ but did not affect daily
\end{abstract}

\footnotetext{
*Supported by Turkish Republic State Planning Organization (2003K120320D06) and the Scientific

Research Projects Unit of Cukurova University (ZF2009YL84)

${ }^{3}$ Corresponding author: e-mail: gorgulu@cu.edu.tr
} 
gain or the feed-to-gain ratio $(\mathrm{P}>0.05)$. The choice-fed calves had a higher meal number and eating rate and a lower meal duration and intermeal interval $(\mathrm{P}<0.01)$ than the single-fed calves.

In conclusion, the results showed that calves had meal criteria of approximately 5 to $8 \mathrm{~min}$, 11-18 meals per day, a 66- to 82 -g meal size, and a 6- to 11 -min meal duration. The results also showed that pre-weaning calves selected a diet containing a higher crude protein content $(31-35 \%)$ than the standard starter crude protein content $(18 \%)$.

KEY WORDS: calf, diet choice, season, eating behaviour

\section{INTRODUCTION}

Young animals that follow their parents and feed together with them can learn to select food types (Phillips and Youssef, 2003). In intensive dairy production, calves are separated from the mother at an early age and have limited visual contact with their parents and peers. This practice may cause calves difficulty in learning to consume safe and nutritious feeds to meet all nutrient requirements according to their physiological status. Simitzis et al. (2008) reported that young animals have some degree of innate ability to consume and/or choose feeds to meet their nutrient requirements and to avoid certain toxins in the feeds. There is insufficient information, however, about the performance and feeding behaviour of dairy calves under different climate conditions with different feeding methods during the pre-weaning period. Animals under heat stress reduce their feed intake and show lowered immunity. Coupled with increased maintenance energy needs, these factors can produce poor growth and higher susceptibility to disease (Stott et al., 1976). To combat heat stress, animals decrease their feeding activity, divert it to a cooler time of the day, and increase concentrate intake by selecting feeds for behavioural adaptation (Silanikove, 2000). Yurtseven and Gorgulu (2004) showed that goats increase concentrate intake and reduce roughage intake to minimize the heat increment in their bodies at a high environmental temperature if the feed ingredients are available on a free-choice basis. It was also recently found that choice-fed lambs (Rodriguez et al., 2007) and goats (Gorgulu et al., 2008) are able to correctly meet their nutrient requirements by selecting a diet corresponding to their physiological status and environmental conditions. If preweaned calves have this ability, it could be effective for them as well. Therefore, it is expected that calves select different diets if they are subjected to different climatic conditions. The expected changes in eating patterns and preferences will also affect their growth performance and ruminal development.

Moreover, information about diurnal feeding activity is essential to design feeding systems and feeding apparatuses, to obtain information about the composition and physical characteristics of the feed consumed, especially by 
choice-fed animals, to understand the nutritional requirements of animals, and to improve animal health and welfare. There is little information in the literature, however, about diurnal feeding patterns (e.g., meal criteria, meal size, and meal length) of pre-weaned calves supplied with solid feeds.

Accordingly, this study was conducted to test the effect of choice feeding on the growth performance and feeding behaviour of dairy calves and their ability to select their own diet from the choices offered in different seasons in association with shifts in their nutrient requirements.

\section{MATERIAL AND METHODS}

\section{Animals, feeding and management}

A total of 40 male calves ( 20 calves for each season) was used in the summerand winter-season studies. The initial liveweight was $40.20 \pm 0.71$ and $36.40 \pm 0.89$ $\mathrm{kg}$ per calf for the summer and winter studies, respectively. The winter study was performed from late August through November (temperature: $21.28{ }^{\circ} \mathrm{C}$; relative humidity: $61.74 \%$; and temperature-humidity index: 67.61$)$, whereas the summer study was performed from May through August (temperature: $27.90^{\circ} \mathrm{C}$; relative humidity: $28.21 \%$; and temperature-humidity index: 72.50$)$. Ten calves ( $8 \mathrm{~d}$ old) were assigned to each experimental group and weaned at the end of 9 weeks. The calves assigned to each group were born within a 2-wk period and were housed in a barn. The northern opening and the roof of the barn were closed, and the other sides were open. Each calf was kept in an individual pen $(1.5 \times 1.5 \times 1.5 \mathrm{~m})$. Conventionally, each calf was offered whole milk daily in a plastic bucket: 21 in the morning and 21 in the evening during the experimental period. The chemical composition of the milk was as follows, \%: dry matter (DM) 12.5, fat 3.9, total protein 3.5 , casein 2.7 and lactose 4.2 for the summer study and DM 13.3, fat 4.4, protein 3.7, casein 2.9 and lactose 4.3 for the winter study. The differences in milk composition in the different seasons may be attributed to the difference in the colostrum content of the milk used in calf feeding in the different seasons because calving occurred primarily during the cool season at the experimental farm. The feeding methods used were single feeding and choice feeding. The calves under the single-feeding method received a diet containing $20 \%$ ground lucerne hay (1.5-cm to $2-\mathrm{cm}$ in size) ad libitum (Table 2). The calves under the choice-feeding method received all feed ingredients used in the single feed on a free-choice basis ad libitum during the 8 weeks of the study. The single feeds were formulated with barley, maize, wheat bran, soyabean meal, maize gluten meal and lucerne hay (Table 1). The ingredients and nutrient content of the single feed and the diet selected by the calves are shown in Table 2 . 
Table 1. Nutrient contents of feed ingredients used in the diet, $\%$

\begin{tabular}{lccccccc}
\hline Ingredients & $\begin{array}{c}\text { Dry } \\
\text { matter }\end{array}$ & $\begin{array}{c}\text { Crude } \\
\text { protein }\end{array}$ & ADF & NDF & $\begin{array}{c}\text { Crude } \\
\text { ash }\end{array}$ & $\begin{array}{c}\text { Ether } \\
\text { extract }\end{array}$ & $\begin{array}{c}\text { Crude } \\
\text { fibre }\end{array}$ \\
\hline Winter & & & & & & & \\
$\quad$ maize & 88.03 & 11.52 & 4.0 & 9.0 & 3.0 & 2.6 & 1.84 \\
$\quad$ barley & 91.65 & 11.98 & 6.7 & 18.0 & 2.8 & 2.4 & 4.72 \\
$\quad$ wheat bran & 89.85 & 15.26 & 12.6 & 37.0 & 4.1 & 3.7 & 9.39 \\
$\quad$ soyabean meal & 90.22 & 41.86 & 10.2 & 22.9 & 7.6 & 0.9 & 3.62 \\
$\quad$ maize gluten meal & 90.64 & 62.03 & 13.8 & 22.8 & 4.9 & 1.7 & 0.88 \\
$\quad$ lucerne hay & 92.54 & 12.36 & 43.0 & 50.1 & 7.2 & 0.8 & 32.49 \\
Summer & & & & & & & \\
$\quad$ maize & 91.83 & 9.72 & 4.62 & 11.22 & 4.54 & 4.72 & 3.13 \\
$\quad$ barley & 91.93 & 11.29 & 6.62 & 17.26 & 4.33 & 1.15 & 5.17 \\
$\quad$ wheat bran & 92.80 & 15.76 & 15.78 & 47.84 & 5.70 & 2.71 & 11.66 \\
$\quad$ soyabean meal & 93.47 & 43.03 & 9.75 & 29.88 & 7.16 & 0.87 & 5.89 \\
$\quad$ maize gluten meal & 94.26 & 58.60 & 10.28 & 6.49 & 5.04 & 2.03 & 2.20 \\
$\quad$ lucerne hay & 94.46 & 13.00 & 42.31 & 56.71 & 8.00 & 0.54 & 34.52 \\
\hline ADF - acid detgent
\end{tabular}

ADF - acid detergent fibre, NDF - neutral detergent fibre

Table 2. Feed ingredients (\%) and nutrient contents of total mixed ration and the diets selected by calves

\begin{tabular}{|c|c|c|c|c|c|c|}
\hline \multirow{2}{*}{$\begin{array}{l}\text { Feeding method } \\
\text { Season }\end{array}$} & \multicolumn{2}{|c|}{ Single feed } & \multicolumn{2}{|c|}{ Choice feeding } & \multirow{2}{*}{ SEM } & \multirow{2}{*}{$\mathrm{P}<1$} \\
\hline & summer & winter & summer & winter & & \\
\hline \multicolumn{7}{|l|}{ Ingredients } \\
\hline maize & 12.00 & 12.00 & $8.32^{*}$ & $8.95^{* *}$ & 1.3 & 0.73 \\
\hline barley & 42.56 & 42.56 & $9.91^{* *}$ & $6.89^{* *}$ & 2.01 & 0.30 \\
\hline wheat bran & 6.96 & 6.96 & $8.81^{* *}$ & $12.65^{*}$ & 2.26 & 0.24 \\
\hline soyabean meal & 5.92 & 5.92 & $69.75^{* *}$ & $59.57^{* *}$ & 4.59 & 0.13 \\
\hline maize gluten meal & 9.60 & 9.60 & $1.71^{* *}$ & $1.85^{* *}$ & 0.38 & 0.78 \\
\hline lucerne hay & 20.00 & 20.00 & $1.50^{* *}$ & $10.09^{* *}$ & 0.56 & 0.00 \\
\hline additives & 2.96 & 2.96 & 2 & 2 & & \\
\hline \multicolumn{7}{|l|}{ Analysed } \\
\hline DM, \% & 92.95 & 91.33 & $93.14^{*}$ & $90.3^{* *}$ & 0.06 & 0.00 \\
\hline $\mathrm{ME}, \mathrm{Mcal} / \mathrm{kg}$ & 2.44 & 2.44 & $2.76^{* *}$ & $2.65^{* *}$ & 0.025 & 0.01 \\
\hline crude protein, $\%$ & 17.84 & 18.45 & $34.52^{* *}$ & $31.11^{* *}$ & 1.42 & 0.10 \\
\hline $\mathrm{ADF}, \%$ & 14.49 & 14.75 & $10.04^{* *}$ & $13.08^{*}$ & 0.54 & 0.00 \\
\hline NDF, $\%$ & 25.75 & 24.88 & $28.66^{* *}$ & 25.83 & 0.69 & 0.01 \\
\hline crude ash, $\%$ & 8.07 & 6.92 & $6.51^{* *}$ & $6.33^{* *}$ & 0.1 & 0.22 \\
\hline ether extract, $\%$ & 1.60 & 1.98 & $1.39^{*}$ & $1.52^{* *}$ & 0.07 & 0.19 \\
\hline
\end{tabular}

differences between single feed and the diets selected by calves $* \mathrm{P}<0.05,{ }^{*} * \mathrm{P}<0.01 ;{ }^{1}$ difference between seasons; ${ }^{2}$ feed ingredient except lucerne hay supplemented with $1.9 \%$ limestone, $1 \%$ DCP, $0.7 \%$ salt, $0.1 \%$ vitamin-mineral mixture providing, per kg; IU: vit. A 8.000.000, vit. $\mathrm{D}_{3} 1.000 .000$; g: vit. E 30, Mn 50, Zn 50, Fe 50, Cu 10; mg: Co 150, I 800, Se 150

After weaning, the study was extended (post-weaning period) for 2 weeks to compare the diet selected by the calves that were consuming milk with the diet selected by the weaned calves to determine diet selection before and after weaning. All calves were exposed to the same experimental treatment after weaning. 
The liveweight, liveweight gain, and feed intake were determined weekly. The feeds were offered ad libitum (refusals on the last day of the week were noted) and given to the animal by adding fresh feed or feed ingredients daily during the entire duration of the experiment.

To record the diurnal eating patterns of the calves, a recording system was developed and installed. The system included six scales of $30 \pm 0.005 \mathrm{~kg}$ capacity connected to a computer with a serial multiplier. The system recorded the meal size and meal length if each scale attained stability $5 \mathrm{~s}$ after a change in the weight on the scale for $24 \mathrm{~h}$. Because only one real-time data recording system was placed in the experimental enclosure, one calf from each treatment group was kept in the system on alternate days. A total of seven calves for each treatment was observed biweekly.

\section{Calculations}

The chemical compositions of the feeds were analysed using AOAC (1998) procedures. ADF and NDF analyses were based on the method of Van Soest et al. (1991).

Animals eat in discrete meals separated by an intermeal interval. Short intrameal intervals also occur. To define a meal, a criterion is required by which these two types of intervals may be distinguished (Rook and Huckle, 1995). The meal criteria, the longest non-feeding intervals accepted as part of a meal, were calculated as the point at which the probability density functions of the final two populations cross, based on the parameters of the two- and three-population Gaussian models. This approach minimizes the misassignment of intervals to the wrong populations (Tolkamp and Kyriazakis, 1999; Yeates et al., 2001). The models were fitted with nonlinear curve-fitting methods to the pooled and $\log _{\mathrm{e}}-$ transformed interval lengths (expressed in seconds) between feeding events. The meal criteria for the four experimental groups (i.e. winter season-single feeding, winter season-choice feeding, summer season-single feeding, and summer seasonchoice feeding) were determined to be $7.43,6.58,8.04$, and 5.1 min, respectively. Based on this information, the eating patterns of the calves (i.e. the eating rate, meal size, meal length, intermeal interval, meal number and total duration of eating) were determined for these experimental groups.

\section{Statistical analysis}

The experiment was performed according to a completely randomized design with a 2 (season) x 2 (feeding method) factorial arrangement. The data obtained were analysed with the GLM procedure of SPSS with Duncan's multiple range 
test. The difference between the diets selected by the calves and the single feed was calculated with a one-sample $t$ test, and the difference between the diets selected by the calves during the different experimental periods was calculated with a t test (Windows version of SPSS, release 10.01).

\section{RESULTS AND DISCUSSION}

\section{Physiological response}

The observed parameter values were higher during the summer than during the winter (Table 3 ). The season was an important factor for rectal temperature, respiration and pulse rates $(\mathrm{P}<0.01)$. The feeding method affected only the rectal temperature $(\mathrm{P}<0.01)$, which was lower for the single-fed calves than the choicefed calves during the summer. The morning values of the rectal temperature and respiration rate were lower $(\mathrm{P}<0.01)$ than the afternoon values. No interaction was determined between the season, feeding methods, or time of measurements.

Table 3. Physiological response of calves fed different feeding methods in different seasons

\begin{tabular}{|c|c|c|c|c|c|c|c|c|c|c|c|}
\hline \multirow[b]{2}{*}{ Parameters } & \multicolumn{3}{|c|}{ Summer } & \multicolumn{4}{|c|}{ Winter } & \multirow{3}{*}{ SEM } & \multicolumn{3}{|c|}{ Effects, $\mathrm{P}<^{*}$} \\
\hline & & $\begin{array}{l}\text { igle } \\
\text { eed } \\
\end{array}$ & $\begin{array}{l}\text { choice } \\
\text { feeding }\end{array}$ & $\begin{array}{l}\text { sing } \\
\text { fee }\end{array}$ & & $\begin{array}{l}\text { chn } \\
\text { fee }\end{array}$ & $\begin{array}{l}\text { oice } \\
\text { ding }\end{array}$ & & \multirow[t]{2}{*}{$\mathrm{S}$} & \multirow[t]{2}{*}{ FM } & \multirow[t]{2}{*}{ SxFM } \\
\hline Time, $\mathrm{h}$ & 10.00 & 14.00 & $10.00 \quad 14.00$ & 10.00 & 14.00 & 10.00 & 14.00 & & & & \\
\hline$\overline{\mathrm{T}_{\mathrm{p}},{ }^{\circ} \mathrm{C}}$ & 39.00 & 39.28 & $\begin{array}{ll}39.15 & 39.37\end{array}$ & 38.61 & 38.89 & 38.72 & 39.04 & 0.07 & 0.00 & 0.06 & 0.00 \\
\hline $\begin{array}{l}\text { PR, beat } \\
\text { per min }\end{array}$ & 101.5 & 104.5 & 102.85105 .06 & 86.83 & 87.31 & 86.31 & 88.23 & 2.39 & 0.00 & 0.63 & 0.26 \\
\hline $\begin{array}{l}\mathrm{RR} \text {, breath } \\
\text { per min }\end{array}$ & 57.33 & 67.82 & $57.11 \quad 67.68$ & 38.55 & 44.32 & 44.63 & 48.60 & 3.48 & 0.00 & 0.31 & 0.00 \\
\hline
\end{tabular}

Although there were some changes in physiological responses of calves due to the season, the calves were not drastically affected and performed well during both seasons.

The increased respiration rate, pulse rate, and rectal temperature of the calves exposed to a high ambient temperature confirmed the results of previous studies (Zöhner et al., 2004; Kristensen and Lovedahl, 2006). Rawson et al. (1989) compared calves reared at $17^{\circ} \mathrm{C}$ and $-30^{\circ} \mathrm{C}$ and reported a decrease in rectal temperature and an increase in the pulse rate because of the low temperature, but no changes in growth performance (a similar finding was obtained in the present study). It is well known that heat-load exposure in livestock produces a slight increase in body temperature and a clear increase in respiration and pulse rates 
(Marcillac-Embertson et al., 2009). In contrast, the high rectal temperature of the choice-fed calves ( 39.07 vs $38.95 ; \mathrm{P}=0.06$ ) compared with the calves fed the single diet may be explained by the metabolic cost of high nitrogen intake (Schroeder and Titgemeyer, 2008) and the increased feeding activity (Terre et al., 2006; Table 3) of the choice-fed calves. Nonetheless, the performance of the calves suffering heat stress was similar to that of the unstressed calves. This finding could be explained by the greater ratio of body surface area to body mass and the ability to achieve a rapid increase in the peripheral blood flow to increase heat dissipation as the ambient temperature increased (Spain and Spiers, 1996).

\section{Eating pattern}

The meal criteria for calves fed a single feed and the choice-fed calves during summer and winter were determined to be 8.04, 5.1 and 7.43, $6.58 \mathrm{~min}$, respectively (from pooled data for calves observed in the computerized system) (Table 4). Choice feeding increased the meal number $(11.89$ vs $15.80 ; \mathrm{P}<0.01)$ and the eating rate $(12.16 \mathrm{vs} 17.89 \mathrm{~g} / \mathrm{min} ; \mathrm{P}<0.01)$ and decreased the meal length $(9.02$ vs $6.34 \mathrm{~min} ; \mathrm{P}<0.01$ ) and the intermeal interval ( 83.45 vs $51.00 \mathrm{~min} ; \mathrm{P}<0.01$ ). The season affected the meal number, the eating rate and the total meal time. The meal number and the total meal time were higher during the summer than during the winter $(\mathrm{P}<0.05)$, but the eating rate was lower during the summer. The interaction between the feeding method and the season affected the meal length and intermeal interval $(\mathrm{P}<0.01)$.

Table 4. Eating pattern for calves fed single feed and choice fed calves during winter and summer season

\begin{tabular}{|c|c|c|c|c|c|c|c|c|}
\hline \multirow{2}{*}{$\begin{array}{l}\text { Season }(\mathrm{S}) \\
\text { Feeding method (FM) }\end{array}$} & \multicolumn{2}{|c|}{ Summer } & \multicolumn{2}{|c|}{ Winter } & \multirow[b]{2}{*}{ SEM } & \multicolumn{3}{|c|}{ Effects, $\mathrm{P}<$} \\
\hline & $\begin{array}{l}\text { single } \\
\text { feed }\end{array}$ & $\begin{array}{l}\text { choice } \\
\text { feeding }\end{array}$ & $\begin{array}{r}\text { single } \\
\text { feed }\end{array}$ & $\begin{array}{l}\text { choice } \\
\text { feeding }\end{array}$ & & $\mathrm{S}$ & FM & SxFM \\
\hline Meal criteria, min & 8.04 & 5.1 & 7.43 & 6.58 & - & - & & - \\
\hline Meal number & 12.6 & 17.75 & 11.15 & 13.85 & 1.29 & 0.04 & 0.01 & 0.35 \\
\hline Meal size, $\mathrm{g} / \mathrm{meal}$ & 81.75 & 66.28 & 66.60 & 73.51 & 8.65 & 0.65 & 0.63 & 0.21 \\
\hline Meal length, min & 10.55 & 6.10 & 7.49 & 6.58 & 0.79 & 0.11 & 0.00 & 0.03 \\
\hline Intermeal interval, min & 78.99 & 64.74 & 87.91 & 37.27 & 7.05 & 0.20 & 0.00 & 0.01 \\
\hline Eating rate, $\mathrm{g} / \mathrm{min}$ & 11.12 & 16.57 & 13.20 & 19.20 & 1.10 & 0.04 & 0.00 & 0.81 \\
\hline Total meal time, min/day & 136.29 & 108.24 & 83.40 & 99.11 & 13.79 & 0.03 & 0.66 & 0.12 \\
\hline Total feed intake, $g /$ day & 1048.93 & 1150 & 797.11 & 1163.88 & 156.54 & 0.46 & 0.15 & 0.41 \\
\hline
\end{tabular}

Choice feeding did not affect the intermeal interval during the summer (78.99 vs $64.74 \mathrm{~min}$ ), but it decreased the intermeal interval (87.91 vs $37.27 \mathrm{~min}$ ) during the winter. In addition, choice feeding decreased the meal length during the summer but did not affect the meal length during the winter. 
The choice-fed calves had free access to six different feed ingredients (maize, barley, wheat bran, maize gluten meal, soyabean meal, and lucerne hay). Thus, offering multiple choices may encourage feed intake and feeding activity (Gorgulu et al., 2008). The higher feed intake in both seasons for the choice-fed calves (Table 4) is evidence that feed intake is stimulated if different feed ingredients are offered simultaneously. The decrease in meal duration for choice-fed calves is a reflection of the increase in the meal number and in the rate of feed intake compared with single-fed calves.

We know of no studies of the meal criteria in calves with solid feed intake. Meal criteria have been found to be $20 \mathrm{~min}$ (Francke et al., 1990), $37.6 \mathrm{~min}$ (Stamer et al., 1997), and $24.43 \mathrm{~min}$ (Boga et al., 2008) for cattle and 10-13 min (Gorgulu et al., 2008) for goats. The differences within species may depend on the diet, genotype, and environmental and physiological status of the animals in addition to the data collection methods used. The meal criterion for calves was shorter than those for adult cattle, sheep, and goats. This difference could be explained by the need to fine-tune the nutrient intake of pre-ruminant calves to meet high nutrient requirements because of their small stomach capacity and undeveloped forestomach (Provenza and Balph, 1990; Provenza, 1995).

The milk-drinking pattern of calves fed milk ad libitum from artificial teats was investigated by Appleby et al. (2001). That study accepted a meal criterion of $60 \mathrm{~s}$ and found the meal number, meal length, and intake rate to be 10 meals per day, $13 \mathrm{~min}$, and $6.44 \mathrm{~g} / \mathrm{s}$, respectively. Similarly, Von Keyserlingk et al. (2004) determined that the meal criteria for milk-fed calves ranged from 2 min to 40.7 min. They also calculated the meal number to be 8-9 meals, based on a meal criterion of $40.7 \mathrm{~min}$. Similar results were reported by De Paula Viera et al. (2007). The results of the studies cited above are not similar to the results of the present study. This difference could be attributed to the feed sources used.

In contrast, the summer season increased meal number and total meal time. This result could be explained by a decrease in the rate of eating during the summer. A similar meal pattern was reported by Rhind et al. (2002) in non-domesticated animals. Similarly, choice feeding increased the meal number significantly. This increase is probably a consequence of the availability of a number of choices (Gorgulu et al., 2008).

\section{Diet selection and growth performance}

Choice-fed calves selected diets markedly different from the single diet in terms of ingredients and nutritional composition (Table 2). They preferred a high level of soyabean meal (single feed: $5.92 \%$ vs choice feeding: $64.65 \% ; \mathrm{P}<0.01$ ) and less barley ( $42.56 \%$ for single feed vs $8.4 \%)$ and lucerne hay $(20 \%$ for single 
feed vs $5.79 \%$ ). Choice-fed calves in both seasons selected a diet containing 2.70 Mcal ME/kg DM, 32.82\% CP, 27.25\% NDF and 11.56\% ADF during the entire pre-weaning period.

The season also had a substantial effect on diet selection by the calves. The calves decreased their intake of lucerne hay during the summer compared with the winter. The calves increased energy intake $\left(2.76 \mathrm{Mcal} \mathrm{kg} \mathrm{DM}^{-1}\right.$ for summer vs 2.65 Mcal kg DM${ }^{-1}$ for winter; $\left.\mathrm{P}<0.01\right)$, protein intake $(34.52 \%$ for summer vs $31.11 \%$ for winter; $\mathrm{P}=0.10$; Table 2$)$ and NDF level $(28.66 \%$ for summer vs 25.83 for winter; $\mathrm{P}<0.01)$ and decreased lucerne $(1.49 \%$ for summer vs $10.09 \%$ for winter) and $\mathrm{ADF}(10.04 \%$ for summer vs $13.08 \%$ for winter; $\mathrm{P}<0.01)$ in the diet selected during the summer compared with that chosen during the winter.

The findings showed that the calves with multiple choices selected a diet containing a high protein level $(32.82 \%)$ similar to that in milk $(27.82 \%$ protein in the milk used in the studies), although they had no experience in selecting a diet during the pre-weaning period. It is well known that the liveweight gained at early ages is in protein and mineral form (Schroeder and Titgemeyer, 2008). Soyabean is a good source of protein and digestible fibre (NRC, 2001). Interestingly, the calves selected high amounts of soyabean meal $(64.65 \%)$, but dairy cows selected small amounts of this meal (1.48\%; Boga et al., 2008) if a similar methodology and similar feedstuffs were used. Calves need high-energy diets also during their early life. Therefore, the calves may have preferentially chosen soyabean meal due to its protein quality and energy content. The choice-fed calves selected a more nutritious diet than the single-fed calves and also maximized their nutrient intake. Atwood et al. (2001) reported that animals having the opportunity to select their diets from multiple choices acted to maximize energy intake.

Furthermore, many researchers observed that young animals learn eating behaviour by watching the adults' behaviour (Philips, 2004). The calves in the present study were separated from their mothers $3 \mathrm{~d}$ after birth and kept in individual pens. Although they were separated and had no chance to observe their dams and herdmates, they selected a diet that allowed them to maintain their growth performance at a level consistent with the standards for the breed. Calves can readily adapt to different feeding schedules (Johannesson and Ladewig, 2000) and show an ability to learn feed cues (e.g., structure, palatability) and post-ingestive effects by sampling novel feeds (Smitzis et al., 2007).

The calves having the opportunity to select a diet changed their diet preferences according to the season. During the summer they selected diets containing higher energy and lower fibre than during the winter. It is well known that ruminants increase their concentrate intake and reduce their roughage intake to minimize the heat increment in their bodies under high environmental temperatures if concentrate and roughage are available as free choices (Silanikove, 2000). 
The diets selected by the calves during the first 2 weeks after weaning were not statistically different, however, from those selected during the last 2 weeks before weaning (Table 5). These results show that the nutrient requirements of calves after weaning might not change markedly, although they did not consume milk (Table 5). Alternatively, the feeds ingested at an early age may affect the feed selection of the calves after weaning (Provenza and Balph, 1988). These findings can be explained because the stomach capacity of newly weaned calves is still limited in terms of volume and functionality. Accordingly, the calves still need high nutrient concentrations in their diet. Similarly, Terre et al. (2006) concluded that newly weaned calves are not metabolically mature, as rumen fermentation end products and digestive enzymes increase in activity and quantity as the age of the calf increases.

Table 5. The diet selected by calves the first two weeks after weaning and post-weaning

\begin{tabular}{|c|c|c|c|c|c|c|c|c|}
\hline \multirow{2}{*}{$\begin{array}{l}\text { Period }(\mathrm{P}) \\
\text { Season }(\mathrm{S})\end{array}$} & \multicolumn{2}{|c|}{ Pre-weaning } & \multicolumn{2}{|c|}{ Post-weaning } & \multirow{2}{*}{ SEM } & \multicolumn{3}{|c|}{$\mathrm{P}<$} \\
\hline & winter & summer & winter & summer & & $\mathrm{P}$ & $\mathrm{S}$ & PxS \\
\hline \multicolumn{9}{|l|}{ Ingredients } \\
\hline maize & 6.5 & 1.42 & 4.95 & 1.48 & 0.88 & 0.41 & 0.00 & 0.38 \\
\hline barley & 6.04 & 6.82 & 5.92 & 6.70 & 2.13 & 0.96 & 0.72 & 1.00 \\
\hline wheat bran & 12.57 & 10.56 & 15.83 & 11.20 & 3.92 & 0.62 & 0.40 & 0.74 \\
\hline soyabean meal & 57.80 & 79.55 & 50.15 & 78.51 & 4.9 & 0.38 & 0.00 & 0.50 \\
\hline maize gluten meal & 2.21 & 0.53 & 0.62 & 0.74 & 0.61 & 0.27 & 0.21 & 0.15 \\
\hline lucerne hay & 14.88 & 1.12 & 22.53 & 1.37 & 2.08 & 0.07 & 0.00 & 0.08 \\
\hline \multicolumn{9}{|l|}{ Analysed } \\
\hline dry matter, $\%$ & 90.47 & 93.28 & 90.66 & 93.28 & 0.06 & 0.15 & 0.00 & 0.15 \\
\hline $\mathrm{ME}, \mathrm{Mcal} / \mathrm{kg}$ & 2.60 & 2.76 & 2.50 & 2.75 & 0.03 & 0.10 & 0.00 & 0.15 \\
\hline crude protein, $\%$ & 30.80 & 37.26 & 27.86 & 37.06 & 1.35 & 0.26 & 0.00 & 0.32 \\
\hline $\mathrm{ADF}, \%$ & 14.85 & 10.47 & 17.48 & 10.59 & 0.73 & 0.07 & 0.00 & 0.10 \\
\hline NDF, $\%$ & 27.51 & 30.83 & 30.27 & 30.96 & 0.9 & 0.12 & 0.03 & 0.15 \\
\hline crude ash, $\%$ & 6.45 & 6.77 & 6.43 & 6.76 & 0.13 & 0.90 & 0.02 & 0.95 \\
\hline ether extract, $\%$ & 1.47 & 1.14 & 1.51 & 1.15 & 0.09 & 0.74 & 0.00 & 0.86 \\
\hline
\end{tabular}

Depending on the changes in diet preferences, feed intake and macronutrient intake changed significantly $(\mathrm{P}<0.05)$, and feed intake, ME, CP and NDF intakes were higher $(\mathrm{P}<0.05)$ in the choice-fed calves than in the single-fed calves. The daily gain and feed conversion ratio were not affected by the season, the feeding method, or the interaction of both factors.

A high feed intake by the choice-fed calves resulted in a higher daily gain than that of the single-fed calves (512 vs $473 \mathrm{~g} \mathrm{~d}^{-1}$, respectively, during the summer season; 532 vs $501 \mathrm{~g} \mathrm{~d}^{-1}$, respectively, during the winter season; $\mathrm{P}>0.05$; Table 6). A lack of response to high feed intake or to the selection of a nutritious diet could be attributed to the level of protein and source of energy in the selected diet. The high levels of protein and NDF consumption of the choice-fed calves 
Table 6. Feed and nutrient intakes, daily gain and feed to gain ratios calves fed different feeding method in different season

\begin{tabular}{|c|c|c|c|c|c|c|c|c|}
\hline \multirow{2}{*}{$\begin{array}{l}\text { Season }(\mathrm{S}) \\
\text { Feeding method (FM) }\end{array}$} & \multicolumn{2}{|c|}{ Summer } & \multicolumn{2}{|c|}{ Winter } & \multirow[b]{2}{*}{ SEM } & \multicolumn{3}{|c|}{ Effects, $\mathrm{P}<$} \\
\hline & $\begin{array}{l}\text { single } \\
\text { feed }\end{array}$ & $\begin{array}{l}\text { choice } \\
\text { feeding }\end{array}$ & $\begin{array}{l}\text { single } \\
\text { feed }\end{array}$ & $\begin{array}{l}\text { choice } \\
\text { feeding }\end{array}$ & & $\mathrm{S}$ & FM & SXFM \\
\hline Initial liveweight, $\mathrm{kg}$ & 40.45 & 39.95 & 36.48 & 36.33 & 1.16 & 0.00 & 0.78 & 0.88 \\
\hline Weaning weight, $\mathrm{kg}$ & 66.92 & 68.65 & 64.56 & 66.10 & 2.28 & 0.29 & 0.48 & 0.97 \\
\hline Daily gain, g/day & 472.57 & 512.43 & 501.25 & 531.57 & 30.86 & 0.44 & 0.26 & 0.88 \\
\hline Feed intake, g/day & 579.04 & 734.62 & 621.05 & 737.25 & 56.24 & 0.69 & 0.02 & 0.73 \\
\hline Feed to gain ratio & 1.26 & 1.44 & 1.23 & 1.39 & 0.09 & 0.64 & 0.09 & 0.94 \\
\hline ME intake, Mcal/day & $1.41^{\mathrm{b}}$ & $2.05^{\mathrm{a}}$ & $1.51^{\mathrm{b}}$ & $1.95^{\mathrm{a}}$ & 0.14 & 0.99 & 0.00 & 0.50 \\
\hline Protein intake, g/day & $103.32^{\mathrm{b}}$ & $274.4^{\mathrm{a}}$ & $114.56^{\mathrm{b}}$ & $230.73^{\mathrm{a}}$ & 17.59 & 0.36 & 0.00 & 0.13 \\
\hline ADF intake, g/day & $83.92^{\mathrm{ab}}$ & $75.445^{\mathrm{b}}$ & $91.61^{\mathrm{ab}}$ & $103.07^{\mathrm{a}}$ & 7.40 & 0.02 & 0.84 & 0.19 \\
\hline NDF intake, g/day & $149.12^{b}$ & $220.12^{\mathrm{a}}$ & $154.53^{\mathrm{a}}$ & $198.3^{\mathrm{a}}$ & $15.2^{\mathrm{b}}$ & 0.59 & 0.00 & 0.38 \\
\hline Crude ash, g/day & 46.76 & 49.72 & 42.99 & 47.71 & 3.88 & 0.46 & 0.33 & 0.82 \\
\hline Ether extract, g/day & $27.30^{\mathrm{a}}$ & $8.73^{\mathrm{c}}$ & $16.21^{\mathrm{b}}$ & $11.14^{\mathrm{c}}$ & 1.43 & 0.00 & 0.00 & 0.00 \\
\hline
\end{tabular}

might play an important role in the limited improvement in daily gain observed in these calves because they also consumed large amounts of feed. High protein intake may increase the energy need for metabolic clearance of ammonia produced during protein metabolism (Schroeder and Tigemeyer, 2008), and the high fibre intake of the choice-fed calves may decrease dietary energy availability (Beauchemin, 1996). In the present study, the calves consumed high amounts of protein and did not simultaneously receive sufficient energy. It is probable that this imbalance resulted in an abundant supply of amino acids to the animal and in an increase in the oxidation of amino acids (Van Der Born et al., 2006). The choice-fed calves in the present study had higher levels of plasma urea (73 vs $33 \mathrm{mg} \mathrm{dl}^{-1}$ ) and lower levels of glucose (66 vs $74 \mathrm{mg} \mathrm{dl}^{-1}$ ) than those receiving a single feed (Boga et al., 2009). These findings could explain the relatively small difference between the daily gain of the choice-fed calves and the daily gain of the calves receiving a single feed. The choice-fed calves showed a higher feed intake but only a slightly higher daily gain. Nevertheless, high preferences for protein during early life may affect calves' future health and performance (Gardner et al., 2009).

\section{CONCLUSIONS}

In conclusion, the study showed that calves have meal criteria of approximately 5 to $8 \mathrm{~min}, 11$ to 18 meals per day, a 66- to 82-g meal size and a meal length of 6-11 min. The study also showed that the pre-weaning calves selected a diet containing higher crude protein $(31 \%-35 \%)$ than the standard starter protein level (18\%). Furthermore, high preferences for protein may affect the future performance of young calves. It is therefore necessary to investigate the effect of the early diet preferences of calves on their subsequent performance. 


\section{REFERENCES}

AOAC, 1998. Association of Official Analytical Chemists, Official Methods of Analysis. 16 $6^{\text {th }}$ Edition. Arlington, VA

Appleby M.C., Weary D. M., Chua B., 2001. Performance and feeding behaviour of calves on ad libitum milk from artificial teats. Appl. Anim. Behav. Sci. 74,191-201

Atwood S.B., Provenza F.D., Wiedmeier R.D., Banner R.E., 2001. Influence of free-choice vs mixedration diets on food intake and performance of fattening calves. J. Anim. Sci. 79, 3034-3040

Beauchemin K.A., 1996. Using ADF and NDF in dairy cattle diet formulation-a western Canadian perspective. Anim. Feed Sci. Tech. 58, 101-111

Boga M., Sahin A., Kılıc U., Gorgulu M., 2009. Behavioural responses of dairy calves to cafeteria feeding vs single feeding. J. Anim. Vet. Advan. 8, 1573-1578

Boga M., Sahinler S., Gorgulu M., Kılıc U., Goncu S., Cebeci Z., Aksoy M., 2008. Obtaining data for meal criterion for dairy cows in a computerized feeding system. In: Proceedings of $4^{\text {th }}$ International Conference HAICTA, Greece, pp. 168-172

De Paula Vieira A., Guesdon V., DePassille A.M., Von Keyserling M.A.G., Weary D.M., 2007. Behavioural indicators of hunger in dairy calves. Appl. Anim. Behav. Sci. 109, 180-189

Francke H., Junge W., Kalm E., 1990. Roughage intake of dairy cows with special consideration of the behaviour. 1. Systematic effects on the roughage intake and the behaviour at the feeding rack. Züchtungskunde 62, 333-348

Gardner D.S., Ozanne S.E., Sinclair K.D., 2009. Effect of the early-life nutritional environment on fecundity and fertility of mammals. Phil. Trans. Royal Soc. London B 364, 3419-3427

Gorgulu M., Boga M., Sahin A., Serbester U., Kutlu H.R., Sahinler S., 2008. Diet selection and eating behaviour of lactating goats subjected to time restricted feeding in choice and single feeding system. Small Ruminant Res. 78, 41-47

Gorgulu M., Guney O., Torun O., Kutlu H.R, Ozuyanik O., 2003. An alternative feeding system for dairy goats: Effects of free-choice feeding on milk yield and milk composition of lactating suckling Damascus goats. J. Anim. Feed Sci. 12, 33-44

Johannesson T., Ladewig J., 2000.The effect of irregular feeding times on the behaviour and growth of dairy calves. Appl. Anim. Behav. Sci. 69, 103-111

Kristensen T.N., Lovedahl P., 2006. Physiological responses to heat stress and their potential use as indicators of reduced animal welfare in Jersey calves. Zoology 52, 681-689

Marcillac-Embertson N.M., Robinson P.H., Fadel J.G., Mitloehner F.M., 2009. Effects of shade and sprinklers on performance, behavior, physiology, and the environment of heifers. J. Dairy Sci. 92, 506-517

NRC, 2001. Nutrient Requirements of Dairy Cattle. $7^{\text {th }}$ Edition. National Academy Press. Washington, DC

Phillips C.J.C., Youssef M.Y.I., 2003. The effects of previous grazing experience and ewe presence on the response to novel grass species by weaned lambs. Anim. Sci. 77, 335-342

Provenza F.D., 1995. Postingestive feedback as an elementary determinant of food preference and intake in ruminants. J. Range Manage. 48, 2-17

Provenza F.D., Balph D.F., 1988. The development of dietary choice in livestock on rangelands and its implications for management. J. Anim. Sci. 66, 2356-2368

Provenza F.D., Balph D.F., 1990. Applicability of five diet selection models to various foraging challenges ruminants encounter. In: R.N. Hudges (Editor). Behavioural Mechanisms of Food Selection. Springer-Verlag. Berlin, Hedielberg, pp. 423-459

Rawson R.E., Dziuk H.E., Good A.L., Anderson J.F., Bates D.W., Ruth G.R., Serfass R.C., 1989. Health and metabolic responses of young calves housed at $-30^{\circ} \mathrm{C}$ to $-8^{\circ} \mathrm{C}$. Can. J. Vet. Res. 53, 268-274 
Rhind S.M., Archer Z.A., Adam C.L., 2002. Seasonality of food intake in ruminants: recent developments in understanding. Nutr. Res. Rev. 15, 43-65

Rodriguez A.B., Bodas R., Fernandez B., Lopez-Campos O., Mantecon A.R., Giraldez F.J., 2007. Feed intake and performance of growing lambs raised on concentrate-based diets under cafeteria feeding systems. Animal 1, 459-466

Rook A.J., Huckle C.A., 1995. Criteria for identifying meals from continuous recordings of the behaviour of grazing dairy cows. Ann. Zootech. 44, Suppl. 1, 105 (Abstr.)

Schroeder G.F., Titgemeyer E.C., 2008. Interaction between protein and energy supply on protein utilization in growing cattle: A review. Livest. Sci. 114, 1-10

Silanikove N., 2000. Effects of heat stress on the welfare of extensively managed domestic ruminants. Livest. Prod. Sci. 67, 1-18

Simitzis P.E., Bizelis J.A., Deligeorgis S.G., Feggeros K., 2008. Effect of early dietary experiences on the development of feeding preferences in semi-intensive sheep farming systems-a brief note. Appl. Anim. Behav. Sci. 11, 391-395

Spain J.N., Spiers D.E., 1996. Effects of supplemental shade on thermoregulatory response of calves to heat challenge in hutch environment. J. Dairy Sci. 79, 639-646

Stamer E., Junge W., Kalm E., 1997. Temporal pattern of feeding of dairy cows kept in groups. Arch. Tierzucht 40, 195-214

Stott G.H., Wiersma F., Menefee B.E., Radwanski F.R., 1976. Influence of environment on passive immunity in calves. J. Dairy Sci. 59, 1306-1311

Terre M., Deavent M., Bach A., 2006. Performance and nitrogen metabolism of calves fed conventionally or following an enhanced growth feeding program during the preweaning period. Livest. Sci. 105, 109-119

Tolkamp B.J., Kyriazakis I., 1999. To split behaviour into bouts, log-transform the intervals, Anim. Behav. 57, 807-817

Van den Borne J.J., Verstegen M.W., Alferink S.J., Giebels R.M., Gerrits W.J., 2006. Effects of feeding frequency and feeding level on nutrient utilization in heavy preruminant calves. J. Dairy Sci. 89, 3578-3586

Van Soest P.J., Robertson J.B., Lewis B.A., 1991. Methods for dietary fiber, neutral detergent fiber, and nonstarch polysaccharides in relation to animal nutrition. J. Dairy Sci. 74, 3583-3597

Von Keyserlingk M.A.G., Brusius L., Weary D.M., 2004. Competition for teats and feeding behaviour by group-housed dairy calves. J. Dairy Sci. 87, 4190-4194

Yeates M.P., Tolkamp B.J., Allcroft D.J., Kyriazakis I., 2001. The use of mixed distribution models to determine bout criteria for the analysis of animal behaviour, J. Theor. Biol. 213, 413-425

Yurtseven S., Gorgulu M., 2004. Effects of grain sources and feeding methods, free-choice vs total mixed ration, on milk yield and composition of German Fawn x Hair crossbred goats in mid lactation. J. Anim. Feed Sci. 13, 417-428

Zöhner M., Schrader L., Hauser L., Keck M., Langhans W., Wechsler B., 2004. The influence of climatic conditions on physiological and behavioural parameters in dairy cows kept in open stables. Anim. Sci. 78, 139-147 